\title{
Determination of Students' Beliefs is one of the Aspects of Competence Oriented System of Mathematics Teachers’ Methodical Preparation
}

\author{
N. A.Tarasenkova*, I. A. Akulenko* \\ Bohdan Khmelnytsky National University at Cherkasy, Cherkasy, Ukraine \\ *Corresponding author: ntaras7@ukr.net; akulenkoira@mail.ru
}

Received September 29, 2013; Revised October 13, 2013; Accepted November 07, 2013

\begin{abstract}
The article analyzes the results of determination of students' - future math teachers' beliefs about the state of their preparation for future professional activities. The measurement and qualitative analysis of students' beliefs concerning their future profession is an important pedagogical problem. The measurement analysis of Ukrainian students' value beliefs (future Mathematics teachers) with the help of the methods proposed in the TEDSM project are compared with the results of analogical investigations in Russia. The beliefs about the nature of mathematics; beliefs about learning mathematics and students' mathematics abilities; students' beliefs about their preparedness level to professional activity were compared. Also "problem zones" for Ukrainian students' value beliefs were reviled.
\end{abstract}

Keywords: Mathematics teachers training, the future teacher of Mathematics, future math teacher's beliefs

Cite This Article: N. A.Tarasenkova, and I. A. Akulenko, "Determination of Students' Beliefs is one of the Aspects of Competence Oriented System of Mathematics Teachers' Methodical Preparation.” American Journal of Educational Research 1, no. 11 (2013): 477-483. doi: 10.12691/education-1-11-4.

\section{Introduction}

Nowadays Ukrainian theorists and practitioners associate the achievement of strategic goals of pedagogical education system with the construction of its main parts on the basis of competence approach as a perspective world and European guide [11]. This approach gained recognition in many European countries, Russia and other countries of CIS. The introduction of competence approach to the Ukrainian system of future specialist training has gone from long-term discussions, debate and reasoning to confirmation in state documents and practical implementation in education process.

Analyzing characteristic state of implementing competence approach to world and particularly Ukrainian education area, Ukrainian scientists note that a teacher's competence reflects the students' system of value beliefs and experience of emotion-value relation to Mathematics Didactics categories, to their profession, to themselves, to pupils, to the society. Therefore, the measurement and qualitative analysis of students' beliefs concerning their future profession is an important pedagogical problem.

Over the last 50 years, the International Association for the Evaluation of Educational Achievement (IEA) has conducted more than 23 large-scale comparative studies of student achievement [5]. The work associated with teacher preparation as well as experience gained in many of IEA's studies, such as TIMSS, led to a request from members of the organization for an in-depth investigation of teacher preparation and training, particularly in terms of the subject area of mathematics.

The necessity of measurements for investigating the main characteristics of value beliefs and future teachers' relations to their future professional activity are confirmed by the experts of international monitoring investigations: G. S. Kovaleva, L. O. Denishcheva, T. A. Koreshkova, Y. A. Semeniachenko, and N. V. Sheveliova [1], M. T. Tatto, J. Schwille, S. Senk, K. Bankov, M. Rodriguez, M. Reckase, L. Ingarson, R. Peck, R. Rowley [2]. The assessment of pedagogical education quality as a part of international project of quality monitoring of Mathematics teachers training TEDS-M (Teacher Education and Development Study in Mathematics 2006 - 2009 [3]) is carried out in two dimensions:

1) determining the level of future Mathematics teachers' preparedness to teaching this discipline on the basis of Mathematics teacher's professional competences that are preliminary selected and reflect the specific features of his activity;

2) determining future teachers' available value beliefs and relations that define their personality position concerning their future professional activity.

We conducted $[9,10]$ a survey among the students obtained Mathematics Teacher qualification in Ukrainian higher schools of III-IV accreditation levels in 2012 (totally 429 persons) with the aim of determining available value beliefs and relations of future Mathematics teachers using research tools of TEDS-M.

\section{Conceptual Framework}


The measurement analysis of Ukrainian students' value beliefs (future Mathematics teachers) with the help of the methods proposed in the TEDS-M project and the comparison of them with the results of analogical investigations in Russia [1].

\section{Beliefs}

Similar to the arguments given about the importance of content and general knowledge in teaching, there is wide agreement that beliefs are an important influence on teaching. Nevertheless, there is no conclusive evidence that beliefs can be effectively influenced by teacher preparation or that they are an intrinsic characteristic of those individuals who become teachers (Tatto\&Coupland, 2003 [3,4]). In TEDS-M, this measurement area is informed by previous work done by the Teaching and Learning to Teach Study at MSU (Deng, 1995; Tatto, 1996, 1998, 1999b, 2003), and by the work of other international scholars (Grigutsch, Raatz, \& Tцrner, 1998; Ingvarson, Beavis, Danielson, Ellis, \& Elliott, 2005; Ingvarson, Beavis, \& Kleinhenz, 2007 [6]). The TEDS-M beliefs scales [2] include questions in five areas: beliefs about the nature of mathematics; beliefs about learning mathematics; beliefs about mathematics achievement; beliefs about preparedness for teaching mathematics; and beliefs about program effectiveness.

According to international experts, the crucial value beliefs and relations of future teachers are: beliefs about the nature of mathematics; beliefs about learning mathematics and students' mathematics abilities; students' beliefs about their preparedness level to professional activity.

\section{Methodology}

The items used to measure Beliefs about the Nature of Mathematics, Beliefs about Learning Mathematics, and
Beliefs about Mathematics Achievement come from a number of studies, including those by Grigutsch et al. (1998) and by Ingvarson et al. (2005, 2007), Deng (1995), the feasibility study for TEDS-M (Schmidt et al., 2007 [7]), and several studies by Tatto (1996, 1998, 1999b, $2003[2,3,4])$. The preparedness scale used in the TEDS$M$ study is based on the ACER Preparedness to Teach inventory, a robust measure based on extensive research (Ingvarson et al., 2005, 2007). For the TEDS-M study [3], the items included measure preparedness to teach in areas such as assessment, management of learning environments, and practices for engaging students in effective learning, and the extent to which teachers become active members of their professional community.

\section{Subjects and Instrument}

The main objective of this study is to examine future teachers' Beliefs about the Nature of Mathematics, Learning Mathematics, about Mathematics Achievement, Preparedness for Teaching Mathematics, about program effectiveness.

\subsection{Beliefs about the Nature of Mathematics}

The items included in this area include questions that explore how future teachers perceive mathematics as a subject (e.g., mathematics as formal, structural, procedural, or applied).

Two scales of students' value beliefs and relations about the Nature of Mathematics "Mathematics as a Cognition Process" and "Mathematics as a Set of Formulas and Procedures" were formed by the experts on the basis of factor analysis. The results of Ukrainian students' questionnaire "Beliefs about the Nature of Mathematics" are the following (Table 1). Russian students' comments are reflected in [[1], p.86].

Table 1. The results of Ukrainian students' questionnaire "To what extent do you agree or disagree with the following beliefs about the nature of mathematics?”

\begin{tabular}{|c|c|c|c|c|c|c|}
\hline & 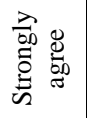 & $\stackrel{\mathscr{d}}{\mathscr{L}_{0}}$ & 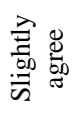 & 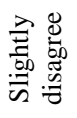 & 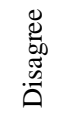 & 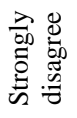 \\
\hline A. Mathematics is a collection of rules and procedures that prescribe how to solve a problem. & 0 & 11,1 & 22,2 & 33,3 & 22,3 & 11,1 \\
\hline $\begin{array}{l}\text { B. Mathematics involves the remembering and application of definitions, formulas, mathematical } \\
\text { facts and procedures. }\end{array}$ & 0 & 27,8 & 44,4 & 11,2 & 5,5 & 11,1 \\
\hline C. Mathematics involves creativity and new ideas. & 50 & 22,2 & 27,1 & 0,1 & 0,1 & 0,5 \\
\hline D. In mathematics many things can be discovered and tried out by oneself. & 38,8 & 33,3 & 16,5 & 11,1 & 0,3 & 0 \\
\hline $\begin{array}{l}\text { E. When solving mathematical tasks you need to know the correct procedure or else you would } \\
\text { be lost. }\end{array}$ & 16,5 & 16,6 & 44,2 & 11,1 & 5,5 & 6,1 \\
\hline $\begin{array}{l}\text { F. If you engage in mathematical tasks, you can discover new things (e.g., connections, rules, } \\
\text { concepts). }\end{array}$ & 16,7 & 38,9 & 27,7 & 11,1 & 3,2 & 2,4 \\
\hline G. Fundamental to mathematics is its logical rigor and preciseness & 27,8 & 61,2 & 5,4 & 5,1 & 0,2 & 0,3 \\
\hline H. Mathematical problems can be solved correctly in many ways & 44,2 & 55,3 & 0,3 & 0,1 & 0,1 & 0 \\
\hline I. Many aspects of mathematics have practical relevance & 50,1 & 44,2 & 5,2 & 0,2 & 0,3 & 0 \\
\hline J. Mathematics helps solve everyday problems and tasks & 27,8 & 44,5 & 27,1 & 0,3 & 0,2 & 0,1 \\
\hline $\begin{array}{l}\text { K. To do mathematics requires much practice, correct application of routines, and problem- } \\
\text { solving strategies. }\end{array}$ & 16,3 & 50,1 & 33,2 & 0,2 & 0,1 & 0,1 \\
\hline L. Mathematics means learning, remembering and applying & 22,2 & 27,3 & 27,6 & 16,1 & 6,3 & 0,5 \\
\hline
\end{tabular}

\subsubsection{Analysis of the Data}

The questionnaire shows that the structure of students' beliefs about the nature of Mathematics is miscellaneous.
There are features of "Mathematics as a Cognition Process" as well as "Mathematics as a Set of Formulas and Procedures" in it. We compare the indexes according the answers of Ukrainian (U) and Russian (R) students (Table 2). 
Table 2. The Comparison of Indexes According to the Answers of Ukrainian (U) and Russian (R) Students

\begin{tabular}{|l|c|c|c|c|}
\hline & \multicolumn{2}{|c|}{$\begin{array}{c}\text { Agreement } \\
\text { zone }\end{array}$} & \multicolumn{2}{c|}{$\begin{array}{c}\text { Disagreement } \\
\text { zone }\end{array}$} \\
\hline & $\mathrm{U}$ & $\mathrm{R}$ & $\mathrm{U}$ & $\mathrm{R}$ \\
\hline $\begin{array}{l}\text { A. Mathematics is a collection of } \\
\text { rules and procedures that prescribe } \\
\text { how to solve a problem. }\end{array}$ & 33,3 & 56,4 & 66,7 & 43,6 \\
\hline $\begin{array}{l}\text { B. Mathematics involves the } \\
\text { remembering and application } \\
\text { of definitions, formulas, } \\
\text { mathematical facts and } \\
\text { procedures. }\end{array}$ & 72,2 & 87,2 & 28,8 & 12,8 \\
\hline $\begin{array}{l}\text { E. When solving mathematical } \\
\text { tasks you need to know the } \\
\text { correct procedure or else you } \\
\text { would be lost. }\end{array}$ & 77,3 & 79,5 & 22,7 & 20,5 \\
\hline $\begin{array}{l}\text { F. If you engage in mathematical } \\
\text { tasks, you can discover new things } \\
\text { (e.g., connections, rules, } \\
\text { concepts). }\end{array}$ & 83,3 & 84,7 & 16,7 & 15,3 \\
\hline $\begin{array}{l}\text { I. Many aspects of mathematics } \\
\text { have practical relevance. }\end{array}$ & 99,5 & 97,3 & 0,5 & 2,7 \\
\hline $\begin{array}{l}\text { L. Mathematics means learning, } \\
\text { remembering and applying }\end{array}$ & 77,1 & 87,5 & 22,9 & 12,5 \\
\hline
\end{tabular}

The comparison shows that among future Mathematics teachers of Russia there are more individuals (by 23\%) who share idea about mathematics as "A Set of Formulas and Procedures". There are fewer differences in the item of the necessity to solve mathematical problems in order to develop creative thinking and preparedness to the independent discovery of new mathematical facts. The comments of Russian and Ukrainian students concerning the expression "When solving mathematical tasks you need to know the correct procedure or else you would be lost" do not differ significantly; and they show the students' belief to learn according a model, when the presentation of the correct scheme for solving a problem is necessary for successful learning. Most of Ukrainian students $(82,2 \%)$ focus on the activity of memorization and application of definitions, formulas, mathematical facts and procedures while learning Mathematics. At the same time, $99.3 \%$ of students consider learning Mathematics to be a creative and cognitive activity that is the basis for the implementation of new discoveries.

\subsection{Beliefs about Learning Mathematics}

\subsubsection{Obtaining the Data}

This area includes questions about the appropriateness of particular instructional activities, questions about students' cognition processes, and questions about the purposes of mathematics as a school subject.

The following scales of students' beliefs were distinguished concerning the peculiarities of learning mathematics [[1], p.92]: 1) learning mathematics is under the guidance of a teacher; 2) pupils learn mathematics mostly be the way of independent education and cognitive activity (Table 3).

Table 3. The results of Ukrainian students' questionnaire "From your perspective, to what extent would you agree or disagree with each of the following statements about learning mathematics?”

\begin{tabular}{|c|c|c|c|c|c|c|}
\hline . & 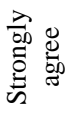 & 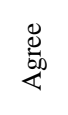 & 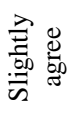 & 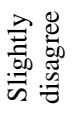 & 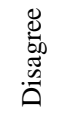 & 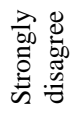 \\
\hline A. The best way to do well in mathematics is to memorize all the formulas (Relation 1) & 4,9 & 19,3 & 19,7 & 28,3 & 20,4 & 7,5 \\
\hline B. Pupils need to be taught exact procedures for solving mathematical problems (Relation 1) & 4,8 & 19,2 & 42,3 & 21,8 & 9,7 & 2,2 \\
\hline $\begin{array}{l}\text { C. It doesn't really matter if you understand a mathematical problem, if you can get the right } \\
\text { answer (Relation 1) }\end{array}$ & 1,7 & 12,4 & 5 & 16,6 & 37 & 27,3 \\
\hline D. To be good in mathematics you must be able to solve problems quickly (Relation 1) & 4,9 & 10,2 & 24 & 31,5 & 22,4 & 7 \\
\hline E. Pupils learn mathematics best by attending to the teacher's explanations (Relation 1) & 4,2 & 25,2 & 30,7 & 24,6 & 13,1 & 2,2 \\
\hline $\begin{array}{l}\text { F. When pupils are working on mathematical problems, more emphasis should be put on getting the } \\
\text { correct answer than on the process followed (Relation 1) }\end{array}$ & 3,7 & 8,3 & 13,5 & 18 & 35,1 & 21,4 \\
\hline $\begin{array}{l}\text { G. In addition to getting a right answer in mathematics, it is important to understand why the } \\
\text { answer is correct ( Relation 2) }\end{array}$ & 32 & 38 & 17,3 & 9,5 & 2 & 1,3 \\
\hline $\begin{array}{l}\text { H. Teachers should allow pupils to figure out their own ways to solve mathematical problems } \\
\text { (Relation 2) }\end{array}$ & 43,4 & 31,2 & 13,5 & 6,3 & 2,7 & 2,9 \\
\hline $\begin{array}{l}\text { I. Non-standard procedures should be discouraged because they can interfere with learning the } \\
\text { correct procedure (Relation 1) }\end{array}$ & 2,7 & 8,2 & 16,4 & 25,2 & 25 & 22,6 \\
\hline J. Hands-on mathematics experiences aren't worth the time and expense (Relation 1) & 2,5 & 9,1 & 13,7 & 19,8 & 38 & 16,9 \\
\hline $\begin{array}{l}\text { K. Time used to investigate why a solution to a mathematical problem works is time well spent } \\
\text { (Relation 2) }\end{array}$ & 19,4 & 37,1 & 29,2 & 6,3 & 3,3 & 4,7 \\
\hline $\begin{array}{l}\text { L. Pupils can figure out a way to solve mathematical problems without a teacher's help. (Relation } \\
\text { 2) }\end{array}$ & 15,9 & 35 & 35,5 & 8,6 & 2,8 & 2,2 \\
\hline $\begin{array}{l}\text { M. Teachers should encourage pupils to find their own solutions to mathematical problems even if } \\
\text { they are inefficient (Relation 2) }\end{array}$ & 17,9 & 31 & 32,7 & 11,4 & 2,7 & 4,4 \\
\hline N. It is helpful for pupils to discuss different ways to solve particular problems (Relation 2) & 33,2 & 38,5 & 12,2 & 10,4 & 3,9 & 1,7 \\
\hline
\end{tabular}

\subsubsection{Analysis of the Data}

The questionnaire shows that the structure of students' beliefs about learning Mathematics is miscellaneous. There are features of beliefs about teacher's priority guidance in the process of acquiring mathematical knowledge by the pupils (beliefs 1), as well as beliefs about pupils' independent work as a dominant of their educational and cognitive activity (beliefs 2). For example, $66.3 \%$ of respondents agree with the statement "B. Pupils need to be taught exact procedures for solving mathematical problems" that forms the scale of the first belief. At the same time, even more students agree with the statements that form the second scale: "H. Teachers should allow pupils to figure out their own ways to solve mathematical problems" (80.6\% in agreement zone), "N. It is helpful for pupils to discuss different ways to solve particular problems" (83.9\% in agreement zone).

The relation of Ukrainian students to the statement "A. The best way to do well in mathematics is to memorize all the formulas" causes an anxiety (43.9\% in agreement zone).

To compare with the data of Russian investigators, agreement zone with such a statement is formed by $21.1 \%$ 
of future Russian teachers. Besides, an alarming fact is that almost one-third (27.1\%) of Ukrainian students agree with the statement "I. Non-standard procedures should be discouraged because they can interfere with learning the correct procedure” (Table 4).

In general, we can say that Ukrainian students demonstrate higher index concerning "Pupils learn mathematics mostly under the guidance of a teacher” if compared with Russian students; and, respectively, lower index concerning "Pupils learn mathematics by the way of active independent education and cognitive activity". Thus, the traditions of authoritarian pedagogy among Ukrainian students, future Mathematics teachers, are rather strong.

Table 4. Some Indexes Comparison of Ukrainian (U) and Russian (R) Students' Answers

\begin{tabular}{|c|c|c|c|c|}
\hline & \multicolumn{2}{|c|}{ Agreement zone } & \multicolumn{2}{|c|}{ Disagreement zone } \\
\hline & $\mathrm{U}$ & $\mathrm{R}$ & $\mathrm{U}$ & $\mathrm{R}$ \\
\hline A. The best way to do well in mathematics is to memorize all the formulas. & 43,9 & 21,1 & 56,1 & 79,9 \\
\hline $\begin{array}{l}\text { Non-standard procedures should be discouraged because they can interfere with learning the correct } \\
\text { procedure }\end{array}$ & 27,1 & 87,2 & 28,8 & 12,8 \\
\hline
\end{tabular}

\subsection{Beliefs about Mathematics Achievement}

\subsubsection{Obtaining the Data}

This area taps into future teachers' beliefs about various teaching strategies used to facilitate learning of mathematics. Other questions explore beliefs about how mathematics learning may take place, and yet others explore the application of attribution theory to teaching and learning interactions (e.g., innate ability for learning mathematics).

To determine this available beliefs, the students were proposed to answer the question: "To what extent do you agree or disagree with each of the following statements about pupil achievement in secondary mathematics?”. The variants of answers and the results of questionnaire are in Table 5.

Table 5. The results of Ukrainian students' questionnaire “To what extent do you agree or disagree with each of the following statements about pupil achievement in secondary mathematics?”

\begin{tabular}{|c|c|c|c|c|c|c|}
\hline & 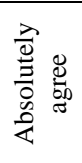 & 总 & 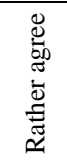 & 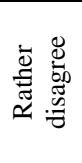 & 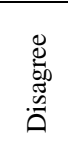 & 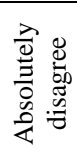 \\
\hline $\begin{array}{l}\text { A. Since older pupils can reason abstractly, the use of hands-on models and other visual aids } \\
\text { becomes less necessary. }\end{array}$ & 4,8 & 19,3 & 19,7 & 28,3 & 20,4 & 7,5 \\
\hline B. To be good at mathematics you need to have a kind of mathematical mind”. & 4,8 & 19,2 & 42,3 & 21,8 & 9,7 & 2,2 \\
\hline C. Mathematics is a subject in which natural ability matters a lot more than effort. & 1,7 & 12,4 & 5 & 16,6 & 37 & 27,3 \\
\hline D. Only the more able pupils can participate in multi-step problem-solving activities. & 4,9 & 10,2 & 24 & 31,5 & 22,4 & 7 \\
\hline E. In general, boys tend to be naturally better at mathematics than girls. & 4,2 & 25,2 & 30,7 & 24,6 & 13,1 & 2,2 \\
\hline F. Mathematical ability is something that remains relatively fixed throughout a person's life & 3,7 & 8,3 & 13,5 & 18 & 35,1 & 21,4 \\
\hline G. Some people are good at mathematics and some aren’t & 32 & 38 & 17,2 & 9,5 & 2 & 1,3 \\
\hline
\end{tabular}

\subsubsection{Analysis of the Data}

The questionnaire shows that while most Russian students (80\%) generally consider that mathematical abilities are constant and cannot be developed or improved in education process, the corresponding index for future Ukrainian teachers is $25.5 \%$.

Thus, the vast majority of future Ukrainian teachers (65,5\%) believe that pupils' mathematical abilities can and must be developed in education process, and education efficiency is achieved due to not only pupils' abilities but corresponding efforts of all participants of education process $(80,9 \%)$.

At the same time, students' gender beliefs are noticed. $60,1 \%$ of our respondents agree with the statement "In general, boys tend to be naturally better at mathematics than girls”.

\subsection{Beliefs about Preparedness for Teaching Mathematics}

\subsubsection{Obtaining the Data}

Table 6. The results of Ukrainian students' questionnaire "Please indicate the extent to which you think your teacher education program has prepared you to do the following when you start your teaching career?”

\begin{tabular}{|c|c|c|c|c|}
\hline & $\begin{array}{c}\text { A major } \\
\text { extent }\end{array}$ & $\begin{array}{l}\text { A moderate } \\
\text { extent }\end{array}$ & $\begin{array}{c}\text { A minor } \\
\text { extent }\end{array}$ & $\begin{array}{c}\text { Not at } \\
\text { all }\end{array}$ \\
\hline A. Communicate ideas and information about mathematics clearly to pupils & 29,1 & 66,3 & 4,6 & 0 \\
\hline B. Establish appropriate learning goals in mathematics for pupils & 33,6 & 55,8 & 9,4 & 1,2 \\
\hline C. Set up mathematics learning activities to help pupils achieve learning goals & 35,2 & 49,7 & 12,2 & 2,9 \\
\hline D. Use questions to promote higher order thinking in mathematics & 22,9 & 51,6 & 21 & 4,5 \\
\hline E. Use computers and ICT to aid in teaching mathematics & 47,7 & 35,6 & 13,5 & 3,2 \\
\hline G. Challenge pupils to engage in critical thinking about mathematics & 21,7 & 55,4 & 17,9 & 5 \\
\hline F. Establish a supportive environment for learning mathematics & 20,9 & 58,1 & 18,7 & 2,4 \\
\hline H. Use assessment to give effective feedback to pupils about their mathematics learning & 27,4 & 58,4 & 11,8 & 2,3 \\
\hline I. Provide parents with useful information about your pupils' progress in mathematics & 24,2 & 48,2 & 20,7 & 7 \\
\hline J. Develop assessment tasks that promote learning in mathematics & 30,7 & 51,8 & 16,7 & 0,8 \\
\hline K. Incorporate effective classroom management strategies into your teaching of mathematics & 22,3 & 49 & 27,2 & 1,5 \\
\hline L. Have a positive influence on difficult or unmotivated pupils & 17,5 & 48,9 & 29,5 & 4,1 \\
\hline M. Work collaboratively with other teachers & 24,8 & 48,9 & 18,2 & 8,1 \\
\hline
\end{tabular}


The fourth area of belief relevant to TEDS-M concerns the extent to which future teachers perceive their teacher preparation has given them the capacity to carry out the central tasks of teaching and to meet the demands of their first year of practice. The items in these scales are therefore designed to explore different areas of teacher preparation impact. At the end of the questionnaire, a direct question is used to confirm these views. To determine how future teachers are confident in their preparedness to professional activity, they were proposed to answer the question "Please indicate the extent to which you think your teacher education program has prepared you to do the following when you start your teaching career?” The variants of answers and questionnaire results are in Table 6.

\subsubsection{Analysis of the Data}

The questionnaire shows that the vast majority of future teachers are rather confident at the start of their professional career; however, a set of a teacher's professional functions within which young specialists are not quite confident, may be distinguished:

- G. Challenge pupils to engage in critical thinking about mathematics (22,9 \%);

- D. Use questions to promote higher order thinking in mathematics (25,5\%);
- F. Establish a supportive environment for learning mathematics (21,1\%);

- I. Provide parents with useful information about your pupils’ progress in mathematics (21,4 \%);

- K. Incorporate effective classroom management strategies into your teaching of mathematics $(28,7 \%)$;

- L. Have a positive influence on difficult or unmotivated pupils (33,6 \%);

- M. Work collaboratively with other teachers (26,3\%).

According to the students' point of view, the study of problem "zones" of their future professional activity will promote the improvement of pedagogical and methodical training system of future specialists.

\subsection{Beliefs about Program Effectiveness}

\subsubsection{Obtaining the Data}

The efficiency of pedagogical education program was assessed by the way of a number of questions:

"In general, how efficient was the program of your preparation to learning Mathematics in basic and special school, in your opinion?”;

"In your teacher preparation program, how often did you have the opportunity to learn to do the following?”;

"During the school experience part of your program, how often were you required to do each of the following?"

Table 7. The results of Ukrainian students' questionnaire "In general, how efficient was the program of your preparation to learning Mathematics in basic and special school, in your opinion?”

\begin{tabular}{|c|c|c|c|c|}
\hline & Absolutely inefficient & Inefficient & Efficient & Very efficient \\
\hline Future Mathematics teachers (concerning basic school) & 2,3 & 4,3 & 73,6 & 19,8 \\
\hline Future Mathematics teachers (concerning senior school) & 0,8 & 13,6 & 71,1 & 14,5 \\
\hline
\end{tabular}

The answer variants and questionnaire results are in Table 7.

As we can see, the vast majority of students generally consider the program of their preparation to teaching Mathematics to pupils of the basic and special school to be efficient (93,4 \% and 85,6 \%, respectively).

However, $14.4 \%$ of the students consider the preparation to the work of Mathematics teacher at special school to be not rather efficient and need to be improved; the corresponding index for the basic school if significantly lower $-6.6 \%$.

The obtained data allow making a conclusion about the topicality of the complex investigation of the problem of future Mathematics teacher methodical preparation for special school that would consider the specific nature of professional functions and tasks which a teacher faces at senior stage of general secondary education.

It is a generally known fact that knowledge criterion is practice, and knowledge efficiency is provided with the experience of its application. Taking into account this fact, the students were proposed a question "In your teacher preparation program, how often did you have the opportunity to learn to do the following” for more detailed assessment of this aspect of future specialist training program. The variants of answers are in Table 8.

Table 8. The results of Ukrainian students' questionnaire "In your teacher preparation program, how often did you have the opportunity to learn to do the following”

\begin{tabular}{|c|c|c|c|c|}
\hline & Often & Occasionally & Rarely & Never \\
\hline A. Develop specific strategies for teaching students with behavioral and emotional problems & 14,2 & 35,9 & 28,7 & 21,3 \\
\hline B. Develop specific strategies and curriculum for teaching pupils with learning disabilities & 15,1 & 40,5 & 37 & 7,4 \\
\hline C. Develop specific strategies and curriculum for teaching gifted pupils & 18,4 & 47,3 & 26,8 & 7,5 \\
\hline D. Develop specific strategies and curriculum for teaching pupils from diverse cultural backgrounds & 9,2 & 27,4 & 27,2 & 36,3 \\
\hline E. Accommodate the needs of pupils with physical disabilities in your classroom & 11,5 & 30,9 & 27,3 & 30,2 \\
\hline F. Work with children from poor or disadvantaged backgrounds & 16,6 & 36,8 & 24,4 & 22,2 \\
\hline G. Use teaching standards and codes of conduct to reflect on your teaching & 38,9 & 41,4 & 15,1 & 4,7 \\
\hline H. Develop strategies to reflect upon the effectiveness of your teaching & 29,4 & 53,8 & 12,8 & 3,9 \\
\hline I. Develop strategies to reflect upon your professional knowledge & 25 & 51,9 & 18,4 & 4,7 \\
\hline J. Develop strategies to identify your learning needs & 18,9 & 48,3 & 23,2 & 9,5 \\
\hline
\end{tabular}

The questionnaire results show that the vast majority of students gets the experience of guiding pupils' learning process while learning Mathematics (90,3\%) and the experience of applying various pedagogical technologies that would influence upon pedagogical skills of young specialists and enrich their pedagogical knowledge.

At the same time, much more attention is paid to practical preparation of future teachers to the work with 
gifted children than with children having emotional, behavioral or cognitive disorders $(65,7 \%$ and 50,1\%, respectively); however, medical, psychological and sociological studies show the increasing number of children having related disabilities.

These aspects should be counted in the process of methodical preparation of the future Mathematics teachers giving them an opportunity to form and enlarge the field of subject experience of interaction with such children.
International experts stress that while assessing the efficiency of education program it is important to consider the succession of theoretical instruction in higher schools and pedagogical practice.

The questionnaire for future teachers included questions that allowed the students to express their pinion concerning how often they used knowledge and skills that were acquired theoretically (Table 8, Table 9).

Table 9. The results of Ukrainian students' questionnaire "During the school experience part of your program, how often were you required to do each of the following?”

\begin{tabular}{|c|c|c|c|c|}
\hline & Often & Occasionally & Rarely & Never \\
\hline A. Observe models of the teaching strategies you were learning in your courses & 48 & 41,5 & 7,1 & 3,4 \\
\hline B. Practice theories for teaching mathematics that you were earning in your courses & 50,1 & 33,1 & 14,1 & 2,7 \\
\hline $\begin{array}{l}\text { C. Complete assessment tasks that asked you to show how you were applying ideas you were learning } \\
\text { in your courses }\end{array}$ & 31,7 & 48,8 & 13,5 & 6 \\
\hline $\begin{array}{l}\text { D. Receive feedback about how well you had implemented teaching strategies you were learning in } \\
\text { your courses }\end{array}$ & 35 & 45,5 & 14,4 & 5,1 \\
\hline E. Collect and analyze evidence about pupil learning as a result of your teaching methods & 45,3 & 34,9 & 18,5 & 1,3 \\
\hline F. Test out findings from educational research about difficulties pupils have in learning in your courses & 24,4 & 44,8 & 22,7 & 8 \\
\hline G. Develop strategies to reflect upon your professional knowledge & 22,2 & 38,1 & 26,6 & 13,1 \\
\hline H. Demonstrate that you could apply the teaching methods you were learning in your courses & 26,5 & 51 & 15,1 & 7,5 \\
\hline
\end{tabular}

\subsubsection{Analysis of the Data}

Let's compare some answers of Ukrainian and Russian students' answers. The obtained answers show that 50.1\% of Ukrainian students often used Mathematics Learning Theories during their practice (the corresponding index for Russia is $66.5 \%$ ). At the same time, $26.5 \%$ of respondents demonstrated the application of learnt education methods in practice (the corresponding index for Russia is much higher $-56.8 \%$ ). Better index is the fact of how often did future teachers collect and analyze pupils' works for getting feedback about education results - 45.3\% (the corresponding index for Russia is $59.7 \%$ ). The important fact that a part of students (26.6\%) seldom developed the approaches for self-estimation of their professional knowledge (the corresponding index for Russia is 30.4\%), never developed such approaches - 13.1\% (the corresponding index for Russia - 9.8\%). These aspects of pedagogical practice deserve our attention as they are connected with the problems of young specialists at the beginning of their pedagogical practice.

\section{Conclusion and Recommendation}

Most future Ukrainian Mathematics teachers are generally confident in their preparedness to professional activity sufficiently and largely according to main positions. At the same, "problem zones" for Ukrainian students are:

1) students' underestimation of the potential of pupils' independent education and cognitive work in learning Mathematics; accordingly, future teachers' confidence in their preparedness to efficient organization and guidance of such pupils' work is insufficient;

2) over $20 \%$ of students noted their insufficient preparedness in the following kinds of methodical activity: the stimulation of pupils to reasoning about mathematics and conducting mathematical reflection; the creation of supportive environment while learning Mathematics; the provision of parents with useful information about pupils' success; positive influence upon the pupils unmotivated to learning Mathematics; close contact with other teachers; the use of efficient ways of guiding a class while learning Mathematics;

3) according to most students (14.4\%), the methodical preparation of future Mathematics teacher of a special school that would consider the specific nature of professional functions and tasks of a teacher in senior school, is not efficient enough;

4) future teachers' practice preparation to the work with gifted children is paid much more attention than with children having emotional, behavioral or cognitive disorders;

5) some aspects of pedagogical practice of future Mathematics teachers require special attention.

Among them, we distinguish the creation of possibilities for: a) students' practical demonstration of education methods that were studied by them theoretically; b) practical checking of data obtained from pedagogical and psychological study concerning pupils' difficulties while learning Mathematics; c) future specialists' selfestimation of their professional knowledge and skills.

\section{Acknowledgement}

We would like to thank the authors of the references who have helped us indirectly through their books, journals while preparing this manuscript.

\section{References}

[1] Kovaleva, G.S., Denyshcheva, L.O., Koreshkova, T.A., Semeniachenko, Y.A., Sheveliova, N.V, Report about Research on the theme: «The Quality of Pedagogical Education in Russia (according to the International Investigation of Study of Pedagogical Education and Estimation of Preparation Quality of Future Mathematics Teachers TEDS» (Final), B.M.I., Moscow, 2010, 174.

[2] Tatto, M. T., Schwille, J., Senk, S., Teacher Education and Development Study in Mathematics (TEDS-M): Policy, practice, and readiness to teach primary and secondary mathematics. Conceptual framework, East Lansing, MI: Teacher Education and 
Development International Study Center, College of Education, Michigan State University, 2008. [E-book]. Available: http://usteds.msu.edu.

[3] Tatto, M. T., Schwille, J., Senk, S., Bankov, K., Rodriguez, M., Reckase, M., Ingvarson, L., Peck, R., Rowley, R, The Mathematics Preparation of Future Primary and Secondary Teachers: Policy, Opportunities to Learn, Knowledge and Beliefs. International Report, Teacher Education and Development International Study Center, College of Education, Michigan State University, 2011.

[4] M. T. Tatto, Empirical measures of teacher quality: Comparative perspectives, Washington, DC: Board of International and Comparative Studies in Education, 2001. [E-book]. Available: http://www4.nationalacademies.org/dbasse/bicse.nsf/web/current. projects

[5] G. Halász, P. Santiago, M. Ekholm, P. Matthews and P. McKenzie, OECD: Attracting, Developing and Retaining Effective Teachers, Country Note, Germany, 2004. [E-book]. Available: http://www.oecd.org/edu/school/33732207.pdf.

[6] Burghes, D, International comparative study in mathematics teacher training research program with the Centre for Innovation in Mathematics Teaching (CIMT). Enhancing the training of teachers of mathematics, Copyright CfBT, 2011, [E-book]. Available: http://www.cimt.plymouth.ac.uk/papers/icsmtt.pdf.

[7] Schmidt, W., Tatto, M. T., Bankov, K., The preparation gap: Teacher education for middle school mathematics in six countries (MT21 report), December, 2007, [E-book]. Available: http://usteds.msu.edu/MT21 Report.pdf.

[8] Even, R., Ball, D.L. (Eds.), The Professional Education and Development of Teachers of Mathematics: The 15th ICMI Study. New CMI Study Series, Springer, New York, 2009.

[9] Akulenko, I. A., "Clarify the problem of future math teachers' of specialized schools methodical training”, Science and Education a New Dimension, Budapest, V. 5, 48-53, 2013.

[10] Akulenko, I., "To the problem of determining the students' future teachers of mathematics - beliefs", Higher Education of Ukraine (Annex 1), special issue of "Pedagogy of higher education: methodology, theory and technology», Vol 2, 504-521, 2012.

[11] Competence approach in modern education: world experience and current prospects, chief editor A.V. Ovcharuk, “KIS”, Kyiv, 2004, 112. 